\title{
Medical genomics at Belyaev Conference - 2017
}

\author{
Yuriy L. Orlov ${ }^{1,2^{*}}$, Julio R. Fernandez-Masso ${ }^{3}$, Ming Chen ${ }^{4}$ and Ancha V. Baranova ${ }^{5,6}$ \\ From Belyaev Conference \\ Novosibirsk, Russia. 07-10 August 2017
}

Current collection continues the series of BioMed Central special post-conference issues presenting the highlights from the set of meetings on bioinformatics and systems biology held in Novosibirsk and Moscow, Russia in 2017.

Year 2017 marks the 100-th anniversary since birth of Professor Dmitry K. Belyaev (1917-1985), Full Member of the USSR Academy of Sciences, world-famous visionary in evolution and genetics. In view of this memorable date, the Institute of Cytology and Genetics of the Siberian Branch of the Russian Academy of Sciences (ICG SB RAS) held international Belyaev Conference on Genetics (Novosibirsk, August 7-10, 2017 - http://conf.bionet.ns c.ru/belyaev100/en). This Memorial Conference included special session on medical aspects of the genomics. In 2017, "Vavilov Journal of Selection and Breeding" published a series of memoirs publications about Prof. Belyaev (http://vavilov.elpub.ru/jour/issue/view/32/ showToc).

Thematic issue of BMC Medical Genomics highlights the studies in medical applications of genome technologies presented at "Belyaev Readings - 2017" (BR-2017) and "High throughput sequencing in genomics" (NGS2017) conferences in Novosibirsk (http://conf.nsc.ru/ HSG2017/ru/hsg2017_hsg_thesis). Modern technologies in medicine more and more become interconnected with advances in sequencing in fundamental evolutionary studies. Previously published special issues of $B M C$ Evolutionary Biology and BMC Genomics covered the proceedings of BGRS $\backslash$ SB-2016 conference and SBB-2015 School in Novosibirsk [1-4] as well as BGRS\SB-2014 event (https://bmcgenomics.biomedcentral.com/articles/ supplements/volume-15-supplement-12). The materials on evolutionary biology and genetics were recently published in BMC Evol Biol (https://bmcevolbiol.biomedcentr

\footnotetext{
* Correspondence: orlov@bionet.nsc.ru

${ }^{1}$ Institute of Cytology and Genetics SB RAS, Novosibirsk, Russia

${ }^{2}$ Novosibirsk State University, Novosibirsk, Russia

Full list of author information is available at the end of the article
}

al.com/articles/supplements/volume-17-supplement-2) and BMC Genetics Supplements (https://bmcgenet.biomedcentral.com/articles/supplements/volume-18-supplement$1)$, correspondingly $[5,6]$.

This issue collected works on sequencing, genotyping, computational analysis and gene network reconstruction in human diseases.

Anastasiya Snezhkina et al. [7] describe exome analysis of carotid body tumors, rare neoplasms of the paraganglia located at the bifurcation of carotid arteries. Exome analysis of 52 carotid body tumor samples for the first time revealed the average mutation load for these tumors and also identified potential driver mutations.

The work by Maxim Ivanov and colleagues [8] discusses the results of using sequencing for ascertainment of genotypes in large group of patients with cystic fibrosis. Authors show that the choice of bioinformatics pipeline plays a crucial role in detecting clinically significant variants and highly influences diagnostic yield.

Yu-Feng Huang et al. [9] continue the theme of cancer research by describing novel way to detect DNA sequence variants in microbial cell-free DNA present in blood. The authors found that the presence of DNA from certain bacterial genera may serve as a predictive biomarker of breast carcinoma outcome.

Ulyana Boyarskikh and colleagues [10] present the results of computational analysis of the genes implicated in the response of lung cancer to certain types of the treatment. In cancer cells, small molecule Nutlin-3 reactivates p53 by interacting with the complex between p53 and its repressor Mdm-2 and causing an increase in cancer cell apoptosis. Using artificial intelligence approach embed in original software, the authors identified a set of transcription factors cooperatively binding to the promoters of genes up-regulated in the Nutlin-3 insensitive cell lines and 
showed that these cell lines are highly sensitive to the dual PI3K/mTOR inhibitors.

Olga Saik et al. [11] showed that associative gene networks analysis aids in dissection of the molecular underpinnings of asthma and hypertension.

Galatenko and colleagues [12] identified the prognostic value for the combinations of expression levels of laminin-encoding genes in colorectal cancer. Importantly, predictive classifiers based on the triples of laminin genes suggest an increased permeability of basal membrane in patients with higher risk of colorectal cancer recurrence.

Abeer Fadda et al. [13] discuss fundamental problem of circadian clock. The authors re-analyzed a number of mouse circadian gene expression data available from public sources. Improved methodology for data mining allowed for the discovery of functions and biological pathways in groups of genes with synchronized peak expression time. In particular, such functions as oxidative phase of energy metabolism, DNA repair, mRNA processing, lipid biosynthesis and others are separated in time.

Andrey Marakhonov et al. [14] described a case of primary, or congenital, microcephaly from the KarachayCherkess Republic, which was initially diagnosed with Seckel syndrome. Clinical exome sequencing of the proband revealed a novel homozygous single nucleotide deletion in ASPM gene. The work represents an additional support for the clinical continuum between Seckel Syndrome and primary microcephaly.

Follow-on series of related works in the areas of genomics, genetics, and plant biology discussed at "Belyaev conference - 2017" and other related meetings in Novosibirsk are published in the Special Issues of BMC Evolutionary Biology (https://bmcevolbiol.biomedcentral.com/articles/ supplements/volume-17-supplement-2), BMC Plant Biology (https://bmcplantbiol.biomedcentral.com/articles/sup plements/volume-17-supplement-2), BMC Genetics (https://bmcgenet.biomedcentral.com/articles/supplements/volume-18-supplement-1) (published at the end of 2017), BMC Genomics (https://bmcgenomics.biomedcentral.com/articles/supplements/volume-19-supplement-3), BMC Structural Biology (https://bmcstructbiol.biomedcentral.com/articles/supplements/volume-18-supplement1) and BMC Neuroscience (https://bmcneurosci.biomedcentral.com/articles/supplements/volume-19-supplement-1) (published in parallel to this issue in 2018). The Proceedings of the conference are available at http://conf.bionet.nsc.ru/belyaev100/en http://conf.bionet.nsc.ru/ belyaev100/wp-content/uploads/sites/14/2017/01/

BELYAEV_conf_2_08_2017.pdf.

The readers are welcome to visit Novosibirsk at the time of next XI-th BGRSISB-2018 conference on August 20-28th in 2018 (http://conf.bionet.nsc.ru/bgrssb2018/en).

\section{Acknowledgements}

The authors and guest editors acknowledge contributions of the Belyaev Conference-2017 Committee, Academicians Vladimir K. Shumny, Mikhail I. Voevoda, Nikolay A. Kolchanov as well as the local conference committee members. The work was supported in part by ICG SB RAS budget project (0324-20180017) and RFBR (17-04-20362).

The conference committee thanks Novosibirsk State University and Zhejiang Bioinformatics Society for organizational and informational support of the meetings. The guest editors are grateful to the reviewers who helped improve science presentation of the materials: Nikolai Barlev (Institute of Cytology RAS, St.Petersburg, Russia), Rafik Neme (Columbia University, USA), Tatiana Tatarinova (University of LaVerne, CA, USA), Oleg Demidov (University of Bourgogne, Dijon, France), Harsha K. Rajasimha (Jeeva Informatics Solutions LLC, USA), Igor Jouline (University of Tennessee, USA), Irina V. Medvedeva (Novosibirsk State University, Russia), Xiaodong Zhao (Shanghai Jiao Tong University, China), Anastasia A. Anashkina (Engelhardt Institute of Molecular Biology RAS Moscow, Russia), Maria A. Tikhonova (SRIPhBM, Novosibirsk, Russia), Dmitry Sonkin (NIH, USA), Ana Brandusa Pavel (Icahn School of Medicine at Mount Sinai, NY, USA), Swati Palit Deb (Virginia Commonwealth University, USA), Liang Sun (University of Delaware, USA), Anna V. Kudryavtseva (Engelhardt Institute of Molecular Biology RAS, Moscow, Russia), Björn Sommer (University of Konstanz, Germany), Udo Schumacher (University Medical Center Hamburg-Eppendorf, Germany), Aybike Birerdinc (GMU-Inova Translational Research Institute, VA, USA), Hiroshi Yasuda (St. Marianna University School of Medicine, Kawasaki, Japan), Junaid Gamieldien (University of the Western Cape, South Africa), Vladimir Babenko (Institute of Cytology and Genetics SB RAS, Novosibirsk, Russia), Elena Semina (Medical College of Wisconsin Milwaukee, WI, USA).

\section{About this supplement}

This article has been published as part of BMC Medical Genomics Volume 11 Supplement 1, 2018: Selected articles from Belyaev Conference 2017: medical genomics. The full contents of the supplement are available online at https:// bmcmedgenomics.biomedcentral.com/articles/supplements/volume-11supplement-1.

\section{Authors' contributions}

$\mathrm{AB}$ and $\mathrm{YO}$ are guest editors of this journal issue. CM and FM are the Conference Committee members. YO, JF, CM and AB wrote the manuscript. All the authors read and approved the final manuscript.

\section{Competing interests}

The authors declare that they have no competing interests.

\section{Publisher's Note}

Springer Nature remains neutral with regard to jurisdictional claims in published maps and institutional affiliations.

\section{Author details}

${ }^{1}$ Institute of Cytology and Genetics SB RAS, Novosibirsk, Russia. ${ }^{2}$ Novosibirsk State University, Novosibirsk, Russia. ${ }^{3}$ Centre of Genetic Engineering and Biotechnology, Havana, Cuba. ${ }^{4}$ Zhejiang University, Hangzhou, China. ${ }^{5}$ Research Centre of Medical Genetics, Moscow, Russia. ${ }^{6}$ George Mason University, Fairfax, VA, USA.

\section{Published: 13 February 2018}

\section{References}

1. Baranova AV, Orlov YL. The papers presented at 7th Young Scientists School "Systems Biology and Bioinformatics" (SBB'15): Introductory Note. BMC Genet. 2016;17(Suppl 1):20. https://doi.org/10.1186/s12863-015-0326-5.

2. Orlov $Y L$, Hofestädt RM, Kolchanov NA. Introductory note for BGRSISB-2014 special issue. J Bioinform Comput Biol. 2015;13(1):1502001. https://doi.org/ 10.1142/S0219720015020011.

3. Orlov YL, Baranova AV, Hofestädt R, Kolchanov NA. Computational genomics at BGRSISB-2016: introductory note. BMC Genomics. 2016; 17(Suppl 14):996. https://doi.org/10.1186/s12864-016-3350-6.

4. Baranova AV, Orlov YL. Evolutionary biology at BGRSISB-2016. BMC Evol Biol. 2017;17(Suppl 1):21. https://doi.org/10.1186/s12862-016-0869-8.

5. Orlov YL, Baranova AV, Herbeck YE. Evolutionary biology at Belyaev Conference-2017. BMC Evol Biol. 2017;17(Suppl 2):260. https://doi.org/10. 1186/s12862-017-1102-0. 
6. Orlov YL, Baranova AV, Tatarinova TV, Kolchanov NA. Genetics at Belyaev Conference-2017: introductory note. BMC Genet. 2017;18(Suppl 1):116. https://doi.org/10.1186/s12863-017-0577-4.

7. Snezhkina AV, Lukyanova EA, Kalinin DV, Pudova EA, Fedorova MS, Stepanov OA, Abramov IS, Golovyuk AV, Pokrovsky AV, Lipatova AV, Yegorov YE, Vishnyakova KS, Moskalev AA, Krasnov GS, Melnikova NV, Shcherbo DS, Alekseev BY, Dmitriev AA, Zaretsky AR, Kudryavtseva AV. Exome analysis of carotid body tumor. BMC Med Genet. 2018;11(Suppl 1):S2. https://doi.org/ 10.1186/s12920-018-0327-0

8. Ivanov M, Matsvai A, Glazova O, Krasovskiy S, Usacheva M, Amelina E, Chernyak A, Ivanov M, Musienko S, Prodanov T, Kovalenko S, Baranova A, Khafizov K. Targeted sequencing reveals complex, phenotype-correlated genotypes in cystic fibrosis. BMC Med Genet. 2018;11(Suppl 1):S3. https:// doi.org/10.1186/s12920-018-0328-Z.

9. Huang $\mathrm{Y}-\mathrm{F}$, Chen $\mathrm{Y}-\mathrm{J}$, Fan $\mathrm{T}-\mathrm{C}$, Chang $\mathrm{N}-\mathrm{C}$, Chen $\mathrm{Y}$-J, Midha MK, Chen $\mathrm{T}-\mathrm{H}$, Yang H-H, Wang Y-T, Yu AL, Chiu K-P. Analysis of microbial sequences in plasma cell-free DNA for early-onset breast cancer patients and healthy females. BMC Med Genet. 2018;11(Suppl 1):S4. https://doi.org/10.1186/ s12920-018-0329-y.

10. Boyarskikh UA, Pintus S, Mandrik N, Stelmashenko D, Kiselev I, Evshin I, Sharipov R, Stegmaier P, Kolpakov FA, Filipenko ML, Kel AE. Computational master-regulator search reveals mTOR and PI3K pathways responsible for low sensitivity of $\mathrm{NCl}-\mathrm{H} 292$ and A427 lung cancer cell lines to cytotoxic action of p53 activator Nutlin-3. BMC Med Genet. 2018;11(Suppl 1):S5. https://doi.org/10.1186/s12920-018-0330-5.

11. Saik OV, Demenkov PS, Ivanisenko TV, Bragina EY, Freidin MB, Goncharova IA, Dosenko VE, Zolotareva OI, Hofestaedt R, Lavrik IN, Rogaev El, Ivanisenko $\checkmark A$. Novel candidate genes important for asthma and hypertension comorbidity revealed from associative gene networks. BMC Med Genet. 2018;11(Suppl 1):S6. https://doi.org/10.1186/s12920-018-0331-4.

12. Galatenko W, Maltseva DV, Galatenko AV, Rodin S, Tonevitsky AG. Cumulative prognostic power of laminin genes in colorectal cancer. BMC Med Genet. 2018;11(Suppl 1):S7. https://doi.org/10.1186/s12920-018-0332-3.

13. Fadda A, Elanbari M, Ptitsyn A. Circadian succession of molecular processes in living tissues. BMC Med Genet. 2018;11(Suppl 1):S8. https://doi.org/10. 1186/s12920-018-0325-2.

14. Marakhonov AV, Konovalov FA, Makaov AK, Vasilyeva TA, Kadyshev W, Galkina VA, Dadali EL, Kutsev SI, Zinchenko RA. Primary microcephaly case from the Karachay-Cherkess Republic poses an additional support for microcephaly and Seckel syndrome spectrum disorders. BMC Med Genet. 2018;11(Suppl 1):S9. https://doi.org/10.1186/s12920-018-0326-1.

\section{Submit your next manuscript to BioMed Central and we will help you at every step:}

- We accept pre-submission inquiries

- Our selector tool helps you to find the most relevant journal

- We provide round the clock customer support

- Convenient online submission

- Thorough peer review

- Inclusion in PubMed and all major indexing services

- Maximum visibility for your research

Submit your manuscript at www.biomedcentral.com/submit

) Biomed Central 